\title{
THE STUDY ON MEDICAL WORKERS EMOTIONAL BURNOUT SYNDROME
}

\author{
Olha Prymachenko ${ }^{1}$, Yevhenii Prokopovych ${ }^{2}$, Serhii Prymachenko ${ }^{3}$ \\ ${ }^{1}$ Lecturer, Institution of higher education "Kyiv Medical College №3", Kyiv (Ukraine) \\ ORCID ID: https://orcid.org/0000-0001-7254-0629 \\ ${ }^{2}$ PhD. in Medical Sciences, Associate Professor of Developmental Psychology Department, Faculty of Psychology, Taras \\ Shevchenko National University of Kyiv, Kyiv (Ukraine) \\ ORCID ID: https://orcid.org/0000-0002-8601-5419 \\ ${ }^{3}$ PhD. in Psychology, Head's assistant, Institution of higher education "Kyiv Medical College №3", Kyiv (Ukraine) \\ ORCID ID: https://orcid.org/0000-0002-7557-2068
}

UDC: $159.9: 61$

\begin{abstract}
The article is important because the problem of emotional burnout is particularly actual one for health professionals in Ukraine and around the world at the moment. The medical staffs of medical departments are exposed to excessive stress on a daily basis in the course of their professional activities due to constant and direct contact with patients who need urgent care or are in a critical psychological state. These circumstances in most cases cause negative emotions, excessive mental stress and physical fatigue. The article purpose was to study of the syndrome of "emotional burnout" and the peculiarities of its manifestation in health professionals depending on gender. The conducted empirical study was devoted to the psychological manifestations of medical workers' emotional burnout among (depending on genders); it was organised in 2020. The special socio-psychological study included 60 medical workers (30 women-nurses and 30 male doctors) with 5 or more years of experience working in medical institutions in Kyiv. The following psychological techniques were used in the empirical study: V.V. Boyko's method determining the level of "emotional burnout"; J. Greenberg's method studying burnout; Maslach Burnout Inventory for "person - person" professions; S.A. Budassi's method for self-assessment; Cattell 16PF Questionnaire. The study results allowed us to draw the following conclusions. Analyzing the link between gender and emotional burnout, we should say that women in a stressful situation are more prone to psychosomatic and psychovegetative disorders, and men are prone to personal alienation (depersonalization). In addition, women's syndrome is manifested not only through "resistance" symptoms - inadequate selective emotional response and reduction of professional responsibilities, but also through experienced traumatic circumstances - a symptom of the "stress" phase, while men's emotional burnout unfolds only via the "resistance" symptoms. Prospects for further research: to consider the problem of burnout factors appeared at medical workers' professional path in a new perspective. Based on the obtained results, we can say that many of the studied health professionals needed specialized psychological care to overcome the emotional burnout syndrome.
\end{abstract}

Key words: emotional burnout syndrome, prevention of emotional burnout syndrome, correction of emotional burnout syndrome, psychological features of medical workers, scientific approaches to the emotional burnout syndrome, psychological features of work with internal resources of a specialist.

Problem statement. The medical staffs of inpatient departments are exposed to excessive stress on a daily basis in the course of their professional activities due to constant and direct contact with patients who need urgent care or are in a critical psychological state. These circumstances in most cases cause negative emotions, excessive

Address for correspondence, e-mail: editpsychas@gmail.com

Copyright: (C) Olha Prymachenko, Yevhenii Prokopovych, Serhii Prymachenko

This is an Open Access journal, all articles are distributed under the terms of the Creative Commons Attribution-NonCommercial-ShareAlike 4.0 International (CC BY-NC-SA 4.0) License (http://creativecommons.org/licenses/by-nc-sa/4.0/), allowing third parties to copy and redistribute the material in any medium or format and to remix, transform, and build upon the material, provided the original work is properly cited and states its license. 
mental stress and physical fatigue, hostility to work, a general vague sense of anxiety, which contributes to the depletion of the psycho-emotional sphere and the development of "professional and emotional burnout". Among the symptoms that appear first, we can distinguish a general feeling of fatigue, a hostile attitude to work, a general uncertain feeling of anxiety, and the perception of work as one that is constantly becoming more complicated and less productive. A medical worker can easily get angry, irritated and feel broken, focus on details and be extremely negative about all events. The anger they feels can lead to suspicion. An employee may think that employees may get rid of them. This condition can be exacerbated by feelings of "noninvolvement", especially if the employee has previously participated in all events. In addition, anyone who tries to help, give advice, is annoying. Serious manifestations of "emotional burnout" are behavioural changes and rigidity. If a person is usually talkative and unrestrained, they may become quiet and estranged. Conversely, a person who is usually quiet and reserved can become very talkative, enter into a conversation with anyone. The victim of "emotional burnout" can become rigid in thinking. A rigid worker is closed to changes because it requires energy or risk, which is a great threat to an already exhausted person.

A healthcare professional who experiences the effects of emotional burnout may try to overcome the situation by avoiding colleagues and patients, physically and spiritually distancing themselves from them. Avoidance and distancing can manifest in many ways. For example, an employee may be absent from work. The can communicate impersonally with colleagues and clients, can reduce their own torment to contact with them. A healthcare professional eventually falls into depression and begins to perceive the situation as "hopeless." They may resign or change their profession altogether.

\section{Analysis of recent research and publications.}

Gender is a social category that defines the totality of all the characteristics that distinguish people depending on gender; is a set of somatic, reproductive, social-cultural and behavioural characteristics.

Medicine is one of the areas of human activity, where quality issues and its evaluation are of particular importance. The main task of social professions is to perform work not for personal consumption, but for the benefit of society; this approach is certainly applied for the medical profession.

Professional and emotional burnout is a syndrome that develops against the background of chronic stress, which leads to depletion of personal resources of emotional energy of a working person. Emotional burnout occurs as a result of the internal accumulation of negative emotions without proper "discharge" or "release" from them. The professional activities of health professionals pose a potential threat to the development of emotional burnout (Sweileh, 2020).

Medical workers' emotional burnout syndrome of is a specific type of professional deformity of people who work in close emotional contact with patients in providing them with professional care. This is a mechanism of psychological protection developed by an individual in the form of complete or partial exclusion of emotions (reduction of their energy) in response to certain traumatic influences. It is characterized by:

1) a feeling of emotional exhaustion (a person cannot give themselves to work as before);

2) dehumanization (tendency to develop a negative attitude towards patients);

3) negative self-education in professional terms lack of sense of professionalism (Chemali, Ezzeddine, Gelaye, Dossett, Salameh, Bizri, et al., 2019).

The occurrence of emotional burnout correlates with a tendency to emotional rigidity, intense internalization (perception and experience) of the circumstances of professional work, weak motivation of emotional impact in professional activities, the presence of moral defects and disorientation (Elbarazi, Loney, Yousef, Elias, 2017). The development of emotional burnout is associated with existing chronic intense psycho-emotional activities: intense communication, reinforcement of emotions, intense perception, processing and interpretation of information and decision-making, as well as poor organization and planning, lack of necessary resources, bureaucratic moments, conflicts with the leader, colleagues, psychologically difficult contingent with which the professional in the field of communication deals.

Healthcare professionals point to many factors as stressors that cause emotional burnout: intense work rhythms, constant reorganizations, the role of uncertainty 
and related conflicts, lack of career growth, inadequate forms of support and control, insufficient ability to influence working conditions (Dugani, Afari, Hirschhorn, Ratcliffe, Veillard, Martin, et al., 2018).

In recent years, society's attitude toward health workers has changed, with patient demands increasing and criticism increasing. The results provide an opportunity to consider in a new perspective the problem of studying the burnout factors in the context of the professional path of an individual health worker.

Existing research (Bresesti, Folgori, De Bartolo, 2020; Roy, 2018) indicate that most of the studied health professionals need specialized psychological care to overcome the syndrome of emotional burnout.

Analysis of psychoprophylaxis and correction of the negative manifestations of emotional burnout showed that, in foreign practice, approaches to its treatment or reduction of its severity are mostly related to techniques taken from the field of coping with stress, which have been effective in overcoming burnout in medical workers.

Strategies to overcome burnout that are based on modifications of the work structure, according to researchers, are the simplest and most effective in reducing the syndrome manifestations (Panagioti, Geraghty, Johnson, Zhou, Panagopoulou, Chew-Graham, et al., 2018). In this regard, it is proposed to limit the number of patients with whom each health worker works; to distribute evenly the most difficult and ungrateful work among team members; to set aside time during the working day for relaxation activities, after which employees restore energy levels; to involve additional employees in work in organizations, for example, volunteers, etc.

As shown in recent researches (Aryankhesal, Mohammadibakhsh, Hamidi, Alidoost, Behzadifar, Sohrabi, et al., 2019; Pastrik, 2017; Horoshkina, 2015), a high level of "exhaustion" was formed at women health workers more often $(30 \%)$ than that at men $(19 \%)$. Analysis of the indicators of the second phase - "resistance" showed that its development was characteristic mostly for women (16\%) and only $4 \%$ of male health workers had this characteristic. As for the "stress" phase, its high level was found only at men (4\%). Thus, we can conclude that at deep development of emotional burnout syndrome, male and female medical employees, working in medical institutions, almost equally respond to stressors being at the first, second phases "exhaustion" and "resistance". However, men are more likely to respond to being at the third syndrome phase "stress".

An in-depth analysis of the symptoms of each phase will allow us to reveal in more detail the relationship between emotional burnout and gender.

Highlighting previously unsolved parts of the general problem to which the article is devoted: to study of the emotional burnout syndrome and the peculiarities of its manifestation in health professionals depending on gender. This is the study purpose.

Research methodology and organization. Research work was conducted during 2020. The special sociopsychological study included 60 medical workers (30 women-nurses and 30 male doctors) with 5 or more years of experience working in medical institutions in Kyiv.

The following psychological techniques were used in the empirical study:

- V.V. Boyko's method determining the level of "emotional burnout" (Boyko, 2017);

- J. Greenberg's method studying burnout (Vodopyanova, 2015);

- Maslach Burnout Inventory for "person - person" professions (Malets, 2018);

- Method for self-assessment of S.A. Budassi (Kosarev, 2017);

- Cattell 16PF Questionnaire of adults' personality traits (Sudakova, 2016).

Presentation of the main research material and discussion. According to the study results shown in Table 1 , the "traumatic circumstances" symptom of the "stress" burnout phase was experienced more often by women health workers $(62 \%)$ than by men $(30 \%)$; in addition, anxiety and depression was also greater at women $(22 \%)$ than at men $(10 \%)$.

At the "resistance" phase, the symptom of inadequate selective emotional response was shown much more often by women $(62 \%)$ than by men $(45 \%)$. Emotional and moral disorientation was experienced equally by women health workers $(21 \%)$ and men health workers $(21 \%)$. The sphere where emotions were saved was expanded more often at men $(30 \%)$ than at women (19\%). Professional responsibilities were reduced more often by women $(50 \%)$ 
DOI (Issue): https://doi.org/10.31108/1.2021.7.4

than by men $(22 \%)$.

The "exhaustion" phase was described by the following burnout symptoms: "emotional deficit" and "emotional withdrawal", which was characteristic equally for men and women (22\%); "personal alienation" (depersonalization), which was characteristic to a greater extent for men (42\%), $22 \%$ of women also had it. "Psychosomatic and psychovegetative disorders" existed more often at women health workers $(17 \%)$ than those at male health workers $(5 \%)$.

As table demonstrates, there were statistically significant differences between genders for the following

gender feel burnout more often, but rather about the specifics of emotional burnout characteristic for different genders (Pastrik, 2017; Horoshkina, 2015).

In addition, scientists determined that, in a stressful situation, men were more prone to emotional alienation, felt urgency, perceived a situation as critical, which often affected their relationships with the environment, provoked alienation from people. Men were less likely to seek social support than women, they often tried to follow the stereotype of "I have to be strong and courageous and decide everything myself".

At the same time, women in a stressful situation

Table 1.

The frequency of symptoms at different emotional burnout phases appearing at medical workers (\%) depending on their gender

\begin{tabular}{|c|c|c|c|}
\hline \multirow{2}{*}{$\begin{array}{c}\text { Burnout symptoms } \\
\end{array}$} & \multicolumn{2}{|c|}{$\begin{array}{c}\text { Gender (number of the respondents in \% having } \\
\text { symptoms) }\end{array}$} \\
\cline { 2 - 4 } & & Women & Men \\
\hline "Stress" phase & Experiencing traumatic circumstances & 62 & 30 \\
\cline { 2 - 4 } & Anxiety and depression & 22 & 10 \\
\hline \multirow{2}{*}{$\begin{array}{c}\text { Resistance" } \\
\text { phase }\end{array}$} & Inadequate selective emotional response & 62 & 45 \\
\cline { 2 - 4 } & Emotional and moral disorientation & 21 & 21 \\
\cline { 2 - 4 } & Expanding the sphere of saving emotions & 19 & 22 \\
\cline { 2 - 4 } & Reduction of professional responsibilities & 50 & 22 \\
\hline \multirow{2}{*}{$\begin{array}{c}\text { "Exhaustion" } \\
\text { phase }\end{array}$} & Emotional deficit & 22 & 20 \\
\cline { 2 - 4 } & Emotional alienation & 20 & $42^{*}$ \\
\cline { 2 - 4 } & Psychosomatic and psychovegetative disorders & $17^{* *}$ & $5^{* *}$ \\
\hline
\end{tabular}

$*$-level of statistical significance $(p<0.01),{ }^{* *}$-level of statistical significance $(p<0.001)$

symptoms of emotional burnout: personal alienation (depersonalization) $(\mathrm{p}<0.01)$ and psychosomatic and psychovegetative disorders $(\mathrm{p}<0.001)$. The obtained data show that women in a stressful situation were more prone to psychosomatic and psychovegetative disorders and men were more prone to personal alienation (depersonalization). In addition, women had not only symptoms of the "resistance" phase - inadequate selective emotional response and reduction of professional responsibilities, but also the "stress" burnout phase - experienced traumatic circumstances, while men's emotional burnout had only "resistance" symptoms.

The data obtained during the empirical study are consistent with the findings of national and foreign studies. Thus, the relationship between emotional burnout and gender is not unambiguous. Some authors argue that men feel burnout more often than women, others ones say on the contrary. Thus, it is not about representatives of what were more prone to emotional exhaustion, they were more emotionally open, tempted to delve emotionally into the experiences of everyone around them (both at work and at home); they endangered their emotional health and risked emotional devastation. Being exhausted emotionally and physically, women acquired psychosomatic and psychovegetative disorders (which they complained much more often compared to men). Women tended to take a maternal position both at home and at work, taking responsibility for the lives and well-being of people around them, which also led to emotional overload, physical and mental exhaustion (especially when a woman was unable to fulfil her responsibilities) (Pastrik, 2017).

The difference in men's and women's behavioural manifestations of emotional burnout can also be explained by the fact that men were dominated by instrumental values, and women were more prone to emotional 


\section{DOI (Issue): https://doi.org/10.31108/1.2021.7.4}

response: they were less likely to be detached from their patients, visitors, people seeking for help.

The risk of burnout also depends on the extent to which the functions performed by employees correspond to their gender and role orientation. Thus, researchers found that men were more sensitive to stressors in situations where they were required to demonstrate purely masculine qualities, such as physical capabilities, masculine courage, emotional restraint, demonstration of their achievements at work. At the same time, women were more sensitive to stressors when they performed duties requiring their compassion, submission.

Another factor influencing burnout at women was the fact that working women experienced higher workloads (compared to men) due to additional domestic and family circumstances (Horoshkina, 2015).

Health professionals' emotional burnout symptoms and phases were re-examined after a special training; the obtained data revealed a positive trend in symptoms and phases of emotional burnout, namely: the number of people with "traumatic circumstances" symptom decreased, this symptom after training had $10 \%$ of the pesrondents; no medical worker at the end of the training had "self-dissatisfaction" or "feeling of being caged" as burnout symptom; the number of anxious and depressed health workers decreased by $4 \%$.

The "stress" phase remained almost unchanged after training; the number of medical workers with the developing symptom decreased slightly (by 4\%).

The number of medical workers having "inadequate selective emotional response", as emerging and developing symptoms dropped by $4 \%$. The number of medical workers with emotional and moral disorientation as a developing symptom decreased by $8 \%$, and by $10 \%$ as a developing symptom. The number of respondents whose sphere of saving emotions expanded decreased by $4 \%$ and $8 \%$ for emerging and developing symptoms, respectively. The number of medical workers with "reduction of professional responsibilities" as emerging symptom decreased sharply by $12 \%$, and as a developing symptom by $4 \%$ of medical workers.

The symptoms of the "exhaustion" phase "emotional alienation", "emotional deficit", "personal alienation" remained almost unchanged after the training. The number of medical workers with psychosomatic and psychovegetative disorders, as an emerging symptom decreased by $2 \%$, and as a developing symptom decreased by $4 \%$ of medical workers. The "exhaustion" phase was found at fewer medical workers: as an emerging symptom, it decreased by $6 \%$ and, as a developing symptom, it decreased by $4 \%$ of medical workers.

Thus, medical workers' burnout syndrome was represented by the "resistance" and "exhaustion" phases, but the number of medical workers with corresponding symptoms decreased slightly, which indicated the feasibility of the proposed psychological work with medical workers.

The repeated study of medical workers' burnout syndrome (with J. Greenberger's method) provided an opportunity to identify the training effectiveness (see Table 2).

As can be seen from Table 2, the analysed dynamics of medical workers' burnout levels showed that the number of medical workers with high burnout levels

Levels of medical workers' burnout before and after the training (\%)

Table 2 .

\begin{tabular}{|l|l|l|l|}
\hline & \multicolumn{1}{|c|}{ Before the training } \\
\hline$№$ & Burnout levels & \multicolumn{2}{|l|}{ Number of the medical workers (\%) } \\
\hline 1 & Low & 26 & 3 \\
\hline 2 & Average & 30 & 30 \\
\hline 3 & High & 44 & 38 \\
\hline
\end{tabular}

Table 3.

Symptoms of medical workers' emotional burnout syndrome before and after the training (\%)

\begin{tabular}{|l|l|l|l|l|l|l|}
\hline \multirow{2}{*}{$\begin{array}{l}\text { The level of } \\
\text { symptoms }\end{array}$} & \multicolumn{4}{|l|}{ Symptoms of the emotional burnout syndrome (number of health workers, in \%) } \\
\cline { 2 - 7 } & Emotional exhaustion & Depersonalization & \multicolumn{2}{l|}{ Reduction of personal achievements } \\
\cline { 2 - 7 } & Before the training & After the training & Before the training & After the training & Before the training & After the training \\
\hline Low & 4 & 8 & 20 & 24 & - & - \\
\hline Average & 54 & 54 & 50 & 48 & 34 \\
\hline High & 42 & 38 & 30 & 28 & 66 \\
\hline
\end{tabular}




\section{DOI (Issue): https://doi.org/10.31108/1.2021.7.4}

decreased by $12 \%$, the number of the respondents with average levels increased by $8 \%$. The number of medical workers with low burnout increased slightly.

Thus, at the end of the experiment, most of the studied health professionals had a burnout syndrome at a presented in table. 4. The number of medical workers with above average (4\%) and high (12\%) self-esteem increased; respectively, the number of workers with low self-esteem decreased by $16 \%$.

The dynamics of medical workers' personal fac-

Table 4.

Health workers' self-assessment before and after the training (\%)

\begin{tabular}{|c|c|c|c|}
\hline \multirow{2}{*}{\multicolumn{2}{|c|}{ Level of self-esteem }} & Before the training & After the training \\
\hline & & \multicolumn{2}{|c|}{ Number of medical workers $(\%)$} \\
\hline Low & & 20 & 4 \\
\hline Below average & & 26 & 26 \\
\hline Average & \multirow[t]{3}{*}{ Adequate } & 34 & 34 \\
\hline Above average & & 16 & 20 \\
\hline High & & 4 & 16 \\
\hline
\end{tabular}

medium level, which indicated the training effectiveness.

The dynamics of medical workers' emotional burnout (with Maslach Burnout Inventory) is shown in table. 3 .

The data obtained for the symptoms of health professionals' emotional burnout showed: high "emotional exhaustion" was found at fewer respondents after training (by $4 \%$ ), respectively, the number of medi- tors before and after training examined with R. Cattell $16 \mathrm{PF}$ questionnaire is shown in tables 5 and 6 . According to the data shown in Tables 5 and 6, we analyzed the psychological profiles of medical workers during the experiment. The Table 6 shows medical workers' personal factors during the experiment.

According to the results shown in table 5, the number of medical workers with average self-esteem in-

Table 5.

Medical workers' personal factors before and after the training (\%)

\begin{tabular}{|c|c|c|c|c|c|c|c|}
\hline \multirow[t]{3}{*}{ № } & \multirow{3}{*}{ Factors } & \multicolumn{6}{|c|}{ Expressiveness of personal factors, in \% } \\
\hline & & Low level & Medium level & High level & Low level & Medium level & High level \\
\hline & & \multicolumn{3}{|c|}{ Before the training } & \multicolumn{3}{|c|}{ After the training } \\
\hline 1 & adequacy of self-esteem & 44 & 30 & 26 & 30 & 44 & 26 \\
\hline 2 & intelligence & 10 & 74 & 16 & 10 & 74 & 16 \\
\hline 3 & trusting-suspiciousness & 40 & 36 & 24 & 30 & 44 & 26 \\
\hline 4 & forthright - shrewd & 36 & 34 & 30 & 36 & 34 & 30 \\
\hline 5 & low - high self-control & 80 & 10 & 10 & 68 & 20 & 12 \\
\hline 6 & relaxed - tensed & 44 & 36 & 20 & 36 & 44 & 20 \\
\hline
\end{tabular}

cal workers with low "emotional exhaustion" increased (4\%); high and medium "depersonalization" was found at less respondents (by 2\%), respectively, increased the number of medical workers with low "depersonalization" after training increased (4\%).

Significant changes were found for the "reduction of personal achievements" symptom after training: the number of medical workers with high levels decreased by $12 \%$ and the number of medical workers with average symptoms increased by $12 \%$.

Thus, the data obtained indicate the effectiveness of the proposed training for health professionals with emotional burnout.

The dynamics of medical workers' self-esteem before and after training with S.A. Budassi's method is creased by $14 \%$, respectively, the number of medical workers with low self-esteem decreased. Medical workers' intelligence, "forthright - shrewd" factor remained unchanged during the experiment. The number of medical workers with high "trusting-suspiciousness" factor increased by $2 \%$, with the medium factor increased by $8 \%$, with the low factor decreased by $10 \%$. Regarding the self-control dynamics, we obtained the following data: the number of medical workers with low self-control decreased by $12 \%$, the number of medical workers with average self-control increased by $10 \%$, and the number of medical workers high self-control increased by $2 \%$. As for "relaxed - tensed" factor: the number of medical workers with low "relaxed - tensed" factor decreased by $8 \%$ and the number of medical workers middle "relaxed - 
Medical workers' psycho-emotional factors before and after the training (\%)

\begin{tabular}{|c|c|c|c|c|c|c|c|}
\hline \multirow[t]{3}{*}{ № } & \multirow[t]{3}{*}{ Factors } & \multicolumn{6}{|c|}{ Expressiveness of personal characteristics, in $\%$} \\
\hline & & Low level & Medium level & High level & Low level & Medium level & High level \\
\hline & & \multicolumn{3}{|c|}{ Before the training } & \multicolumn{3}{|c|}{ After the training } \\
\hline 1 & emotional instability - stability & 84 & 10 & 6 & 64 & 20 & 16 \\
\hline 2 & reserved -outgoing & 50 & 34 & 16 & 50 & 34 & 16 \\
\hline 3 & Group-depended - self-sufficient & 90 & 6 & 4 & 90 & 6 & 4 \\
\hline 4 & Tough-minded - sensitive & 70 & 14 & 16 & 60 & 24 & 16 \\
\hline 5 & self-assured - apprehensive & 44 & 28 & 28 & 28 & 44 & 28 \\
\hline
\end{tabular}

tensed" factor grew by $8 \%$.

The Table 6 shows medical workers' psychoemotional factors during the experiment.

According to the studied dynamics of medical workers' psycho-emotional factors, we found the following data: the number of medical workers with emotional instability decreased (20\%); the number of medical workers with average emotional stability increased by $10 \%$, and the number of medical workers with high emotional stability increased by $10 \%$. The factors of "reserved outgoing" and "group-depended - self-sufficient' did not change. The number of tough-minded health workers decreased by $10 \%$, and the number of health workers with average factor increased by $10 \%$. By the "selfassured - apprehensive" factor, anxiety of health workers decreased by $14 \%$.

The obtained results showed that many health professionals reduced signs of internal personal conflict, causing emotional burnout, which indicates the effectiveness of the proposed psychological training.

Conclusions. The conducted empirical research allowed us to analyse psychological manifestations of medical workers' emotional burnout (depending on genders). The study results have led to the following conclusions. Analyzing the link between gender and emotional burnout, we should say that women in a stressful situation are more prone to psychosomatic and psychovegetative disorders, and men are prone to personal alienation (depersonalization). In addition, women's syndrome is manifested not only through "resistance" symptoms inadequate selective emotional response and reduction of professional responsibilities, but also through experienced traumatic circumstances - a symptom of the "stress" phase, while men's emotional burnout unfolds only via the "resistance" symptoms.

Prospects for further research. The obtained results make it possible to consider the problem of burnout factors appeared at medical workers' professional path in a new perspective. Based on the obtained results, we can say that many of the studied health professionals needed specialized psychological assistance to overcome the emotional burnout syndrome.

\section{References:}

Boyko, V.V. (2017). Energiya emotsiy [Energy of emotions]. SPb.: Piter, 474, [in Russian].

Vodopyanova, N.E. (2015). Sindrom vyigoraniya: diagnostika i profilaktika [Burnout syndrome: diagnosis and prevention]. SPb.: Piter, 336, [in Russian].

Kosarev, V.V. (2017). Nevrozy u meditsinskih rabotnikov [Healthcare workers' neuroses]. Zdorov'ya Ukrayiny, (1), 49, [in Russian].

Malets, L. (2018). Vnimanie: «vyigoranie» [Attention: "burnout”]. Personal, (2), 99-102, [in Russian].

Pastrik, T.V. (2017). Psihologichni osoblivosti emotsiynogo vigorannya v diyalnosti likariv shvidkoyi dopomogi [Psychological features of ambulance doctors' emotional burnout]. Psihol. perspektivi, (17), 186-192, [in Ukrainian].

Sudakova, O.S. (2016). SpetsifIka rozvitku sindromu emotslynogo vigorannya u likariv-onkologIv [The specifics of the development of oncologists' emotional burnout]. Med. PsihologIya, (4), 92-96, [in Ukrainian].

Horoshkina, E. (2015). Professionalnoe vyigoranie spetsialistov [Specialists' professional burnout]. Otdel kadrov, (5), 3-5, [in Russian].

Sweileh, W.M. (2020). Research trends and scientific analysis of publications on burnout and compassion fatigue among healthcare providers. J Occup Med Toxicol 15, 23.

Chemali, Z., Ezzeddine, F.L., Gelaye, B., Dossett, M.L., Salameh, J., Bizri, M., et al. (2019). Burnout among healthcare providers in the complex environment of the Middle East: a systematic review. BMC Public Health.19(1):1337.

Elbarazi, I., Loney, T., Yousef, S., Elias, A. (2017). Prevalence of and factors associated with burnout among health care professionals in Arab countries: a systematic review. BMC Health Serv 
DOI (Issue): https://doi.org/10.31108/1.2021.7.4

$$
\text { Res.17(1):491. }
$$

Dugani, S., Afari, H., Hirschhorn, L.R., Ratcliffe, H., Veillard, J., Martin, G., et al. (2018). Prevalence and factors associated with burnout among frontline primary health care providers in low- and middle-income countries: a systematic review. Gates Open Res. $2: 4$.

Bresesti, I., Folgori, L., De Bartolo, P. (2020). Interventions to reduce occupational stress and burn out within neonatal intensive care units: a systematic review. Occup Environ Med.

Roy, I. (2018). Burnout syndrome: definition, typology and management. Soins Psychiatrie. 39(318):12-9.

Panagioti, M., Geraghty, K., Johnson, J., Zhou, A., Panagopoulou, E., Chew-Graham, C., et al. (2018). Association between physician burnout and patient safety, professionalism, and patient satisfaction: a systematic review and meta-analysis. JAMA Intern Med. 178(10):1317-30.

Aryankhesal, A., Mohammadibakhsh, R., Hamidi, Y., Alidoost, S., Behzadifar, M., Sohrabi, R., et al. (2019). Interventions on reducing burnout in physicians and nurses: A systematic review. Med $J$ Islam Rep Iran. 33(1):77.

\section{Примаченко Ольга Володимирівна}

Викладач, Вищий навчальний заклад «Київський медичний коледж №3», м. Київ (Украӥна)

\section{Прокопович Свгеній Михайлович}

Кандидат медичних наук, Дочент кафедри Психологї Розвитку факультету психології Київського начіонального університету імені Тараса Шевченка, м. Киӥв (Украӥна)

\section{Примаченко Сергій Олексійович}

Доктор філософії у галузі психологї Заступник директора, Вищий навчальний заклад «Київський медичний коледж №3», м. Київ (Украӥна)

\section{ДОСЛІДЖЕННЯ СИНДРОМУ ЕМОЦІЙНОГО ВИГОРАННЯ МЕДИЧНИХ ПРАЦІВНИКІВ}

\section{АНОТАЦІЯ}

Актуальність проблематики статті полягає в тому, що проблема синдрому «емоційного вигорання» $€$ особливо значущою на даний момент серед медичних працівників в Україні та світі. Медичний персонал стаціонарних відділень повсякденно в процесі професійної діяльності піддається надмірним стресовим впливам у зв'язку 3 постійним й безпосереднім контактом 3 хворими, які потребують термінової допомоги або знаходяться в критичному
Volume 7 Issue 4 (48) 2021

психологічному стані. Ці обставини в переважній кількості випадків викликають негативні емоції, надмірну психічну напругу та фізичну втому. Мета статті: опис дослідження 3 вивчення синдрому «емоційного вигорання» та особливостей його прояву у медичних працівників залежно від гендерних ознак. Проведене емпіричне дослідження присвячене аналізу психологічних особливостей прояву емоційного вигорання серед медичних працівників (зв'язок із гендерними чинниками). Дослідницька робота проводилась протягом 2020 року. У спеціальне соціально - психологічне дослідження було включено 60 медичних працівників (30 медичних сестер і 30 лікарівчоловіків) зі стажем роботи 5 та більше років, які працюють в медичних закладах Києва. Тестування проводилося на початку робочого дня. При проведенні емпіричного дослідження були використані наступні психодіагностичні методики: методика діагностики рівня «емоційного вигорання» В.В.Бойко, методика «Досліження синдрому «вигорання» Гринберг Дж., опитувальник «Синдром вигорання» в професіях системи «людина - людина» К. Маслач та С.Джексон, методика самооцінки С.А.Будассі, опитувальник Кеттелла PF-16 тест властивостей особистості дорослих. Результати дослідження дозволили сформулювати наступні висновки. Аналізуючи зв'язок гендерних ознак із емоційним вигоранням, можна стверджувати, що жінки у стресовій ситуації більш схильні до психосоматичних та психовегетативних порушень, а чоловіки - до особистісної відстороненості (деперсоналізації). Крім того у жінок розвиток синдрому відбувається не тільки через «резистенцію» - неадекватне виборне емоційне реагування та через редукцію професійних обов'язків, а ще через переживання психотравмуючих обставин симптом компонента «напруга», в той час коли у чоловіків «емоційне вигорання» розгортається через симптоми лише «резистенції». Перспективи подальших досліджень свідчать про те, що отримані результати дають можливість розглянути у новому ракурсі проблему вивчення чинників вигорання в контексті професійного шляху особистості лікаря. Грунтуючись на отриманих результатах можна говорити, що більшість досліджуваних медичних 
працівників потребують спеціалізованої психологічної допомоги для подолання синдрому емоційного вигорання.

\section{Ключові слюва: синдром емоційного} вигорання, профілактика синдрому емоційного вигорання, корекція синдрому емоційного вигорання, психологічні особливості медичних працівників, підходи до вивчення синдрому емоційного вигорання, психологічні особливості роботи із внутрішніми ресурсами спеціаліста.

\section{Примаченко Ольга Владимировна}

Преподаватель, Киевский медицинский колледж №3, г. Киев (Украина)

\section{Прокопович Евгенй Михайлович}

Кандидат медиичнских наук, Доцент кафедры Психологии Развития факультета психологии Киевского начионального университета имени Тараса Шевченко, г. Киев (Украина)

Примаченко Сергей Алексеевич

Доктор философии в области психологии, заместитель директора, Киевский медицинский колледж №3, г. Киев (Украина)

\section{СИНДРОМ ЭМОЦИОНАЛЬНОГО ВЫГОРАНИЯ МЕДИЦИНСКИХ РАБОТНИКОВ: ПОДХОДЫ К ИЗУЧЕНИЮ}

\section{АННОТАЦИЯ}

Актуальность

проблематики

статьи

заключается в том, что проблема синдрома «эмоционального выгорания» является особо значимой на данный момент среди медицинских работников в Украине и мире. Медицинский персонал стационарных отделений повседневно в процессе профессиональной деятельности подвергается чрезмерным стрессовым воздействиям в связи с постоянным и непосредственным контактом с больными, которые нуждаются в срочной помощи или находятся в критическом психологическом состоянии. Эти обстоятельства в подавляющем числе случаев вызывают негативные эмоции, чрезмерное психическое напряжение и физическую усталость. Цель статьи: описание исследования по изучению синдрома «эмоционального выгорания» и особенностей его проявления у медицинских работников в зависимости от гендерных признаков. Проведенное эмпирическое исследование посвящено анализу психологических особенностей проявления эмоционального выгорания среди медицинских работников (связь с гендерными факторами). Исследовательская работа проводилась в течение 2020 года. В специальное социально психологическое исследование было включено 60 медицинских работников (30 медицинских сестер и 30 врачей-мужчин) со стажем работы 5 и более лет, работающих в медицинских учреждениях Киева. Тестирование проводилось в начале рабочего дня. При проведении эмпирического исследования были использованы следующие психодиагностические методики: методика диагностики уровня «эмоционального выгорания» В.В.Бойко, методика «дослиження синдрома «выгорания» Гринберг Дж., Опросник «Синдром выгорания» в профессиях системы «человек - человек» К. Маслач и С.Джексон, методика самооценки С.А.Будасси, опросник Кеттелла PF-16 тест свойств личности взрослых. Результаты исследования позволили сформулировать следующие выводы. Анализируя связь гендерных признаков с эмоциональным выгоранием, можно утверждать, что женщины в стрессовой ситуации более склонны к психосоматическим и психовегетативных нарушений, а мужчины - к личностной отстраненности (деперсонализации). Кроме того у женщин развитие синдрома происходит не только из-за

«Резистенцию» - неадекватное выборное эмоциональное реагирование и через редукцию профессиональных обязанностей, а через переживание психотравмирующих обстоятельств - симптом компонента «напряжение», в то время как у мужчин «эмоциональное выгорание» разворачивается через симптомы только «резистенции». Перспективы дальнейших исследований свидетельствуют о том, что полученные результаты дают возможность рассмотреть в новом ракурсе проблему изучения факторов выгорания в контексте профессионального пути личности врача. Основываясь на полученных результатах можно говорить, что большинство исследуемых медицинских работников нуждаются в специализированной психологической помощи для преодоления синдрома эмоционального выгорания.

Ключевые слова: синдром эмоционального выгорания, профилактика синдрома эмоционального 
DOI (Issue): https://doi.org/10.31108/1.2021.7.4

выгорания, коррекция синдрома эмоционального выгорания, психологические особенности медицинских работников, подходы к изучению синдрома эмоционального выгорания, психологические особенности работы с внутренними ресурсами специалиста.

\section{How to cite (як цитувати):}

Prymachenko, O., Prokopovych, Y., Prymachenko, S. (2021). THE STUDY ON MEDICAL WORKERS' EMOTIONAL BURNOUT SYNDROME. PSYCHOLOGICAL JOURNAL, 7 (4), 153-162. https:// doi.org/10.31108/1.2021.7.15. 